\title{
TANELLA CAVE (MONTE BALDO - VERONA, ITALY): A RECORD OF ENVIRONMENTAL DATA ON THE LAST GLACIAL PERIOD
}

\author{
JAMA TANELLA (MONTE BALDO - VERONA, ITALIJA): PODATKI \\ O OKOLJU ZADNJE POLEDENITVE
}

\author{
Roberto ZORZIN ${ }^{1}$, Laura AGOSTINI ${ }^{2}$, Maria Chiara MONTECCHI ${ }^{3}$, \\ Paola TORRI ${ }^{3} \&$ Carla Alberta ACCORSI ${ }^{3}$
}

\begin{abstract}
UDC 556.3(450)" $625 "$

Roberto Zorzin, Laura Agostini, Maria Chiara Montecchi, Paola Torri \& Carla Alberta Accorsi: Tanella cave (Monte Baldo - Verona, Italy): a record of environmental data on the Last Glacial period

Since 2003, an extensive hydrogeological investigation has been carried out on Monte Baldo, in order to make a census of springs occurring along the west side of the mountain and to evaluate the quality of their water. The investigation included morphological and hydrogeological observations concerning the Tanella cave and interdisciplinary investigations performed on the deposits found in the cave. This paper shows the first data concerning the hydrogeology of the cave, as well as data on stratigraphy, pollen and micro-charcoals obtained from the analyses of a well preserved sequence located at ca. $80 \mathrm{~m}$ from the entrance (sequence A). The aim of the study was to reconstruct the environment of the area around the cave along the time span testified by the sequence. The sequence is $60 \mathrm{~cm}$ thick and was built up by fluvioglacial sediments followed by lacustrine sediments. Five samples taken along the sequence plus three recent control samples (mosses), collected in places assumed as origins of the pollen input, were studied for pollen and micro-charcoals. Pollen preservation was good and concentration varied from $10^{1}$ to $10^{3} \mathrm{p} / \mathrm{g}$. Pollen spectra from the cave showed the evolution from a landscape of alpine grassland above the timberline, likely of glacial age, to a more forested Holocene landscape similar in flora to the current one testified by the control samples. Pollen probably arrived in the cave by air, water and animals and from plants growing near the cave. It appears to have been continuously underwater after its deposition due to its very good state of preservation. Micro-charcoals suggested that fires were sometimes lit near the cave.

Keywords: cave, hydrogeology, fluvioglacial sediments, pollen.
\end{abstract}

\begin{abstract}
Izvleček UDK 556.3(450)"625"

Roberto Zorzin, Laura Agostini, Maria Chiara Montecchi, Paola Torri \& Carla Alberta Accorsi: Jama Tanella (Monte Baldo - Verona, Italija): podatki o okolju zadnje poledenitve Od leta 2003 se na gori Monte Baldo opravljajo obsežna hidrogeološke raziskave, da bi ugotovili število izvirov na zahodni strani gore ter kakovost njihovih voda. Raziskave vključujejo morfološka in hidrogeološka opazovanja jame Tanella ter interdisciplinarne raziskave tamkajšnjih jamskih sedimentov. Prispevek podaja prve izsledke o hidrogeologiji jame kot tudi o stratigrafiji, pelodu in mikro-oglju, dobljenih s pomočjo analize dobro ohranjenega niza okoli $80 \mathrm{~m}$ od vhoda (sekvenca A). Študija je imela namen rekonstruirati razmere $\mathrm{v}$ jamskem okolju v času, ki ga zavzema omenjeni niz. Niz je debel $60 \mathrm{~cm}$ in ga sestavljajo rečno-ledeniški, na njih pa jezerski sedimenti. Vzdolž niza je bilo vzetih pet vzorcev ter trije recentni za kontrolo (mahovi), nabrani na mestih, od koder se predvideva, da je izviral pelod, za preučevanje peloda in minioglja. Pelod je dobro ohranjen z zgostitvijo med 101 do 103 p/g. Pelodni razpon iz jame kaže na razvoj pokrajine od gorskih travnikov nad gozdno mejo, verjetno iz časa poledenitve, pa do bolj pogozdene holocenske pokrajine s floro, podobno tisti, ki jo dokazujejo kontrolni vzorci. Pelod je bil prinešen v jamo $s$ pomočjo zraka, vode ali živali ter od rastlin, ki so rasle blizu jame. Zelo dobra ohranjenost peloda govori za to, da je bil potem, ko je bil odložen, ves čas pod vodo. Mikro-oglje nakazuje, da je občasno v bližnji okolici jame gorelo.
\end{abstract}

Ključne besede: jama, hidrogeologija, rečno-ledeniški sedimenti, pelod.

\footnotetext{
${ }^{1}$ Museo Civico di Storia Naturale di Verona, Lungadige Porta Vittoria, 9 - Verona, Italy, e-mail: roberto_zorzin@comune.verona.it

${ }^{2}$ IPSIA Enrico Fermi, Piazzale Guardini, 2 - Verona, Italy, e-mail: laura.agostini@istitutofermiverona.it

${ }^{3}$ Università di Modena e Reggio Emilia, Dipartimento del Museo di Paleobiologia e dell'Orto Botanico, Viale Caduti in Guerra, 127 - Modena, Italy, e-mail: m_chiara.montecchi@alice.it; paola.torri@unimore.it; carlaalberta.accorsi@pollenflora.it
} 


\section{INTRODUCTION}

A series of scientific research projects has been carried out in the fields of geology, hydrogeology and karst genetics for almost thirty years now, related to Monte Baldo and the plateau of the Veronese Lessinian Mountains, which are among the most important formations of karst morphology in the Veneto region (Italy).

Concerning Monte Baldo, a series of investigations started in 2003 to make the census of the springs gushing along the Lake Garda side of the mountain and to evaluate the quality of their water.

In 2007, during field investigations, the cave of the "Tanella" spring was also visited (Fig. 1), which opens in the district of Pai (village of Torri del Benaco - Province of Verona). Many sedimentological, morphological and hydrogeological observations were made in the cavity, which gave rise to a new project, named "Tanella". and lacustrine) as well as the typical red soil of karst origin. These materials are rarely deposited inside a cave.

It is often extremely difficult to reconstruct the paleoenvironments related to even very recent intervals, such as those of the last glaciation, for example. In fact, many climatic oscillations have taken place, during which the altitude limits of the zones of vegetation have changed. Since caves are "traps" that collect and preserve sediments and (animal and vegetal) remains of local and/or external origin, studying the microscopic particles in the sediments can make an interesting contribution. Therefore, as a well preserved sequence of fluvioglacial and lacustrine sediments was found in the cave, at about $60 \mathrm{~m}$ from its artificial entrance, pollen and micro-charcoals were studied in it. The aim was to find information about the past plant landscape, climate

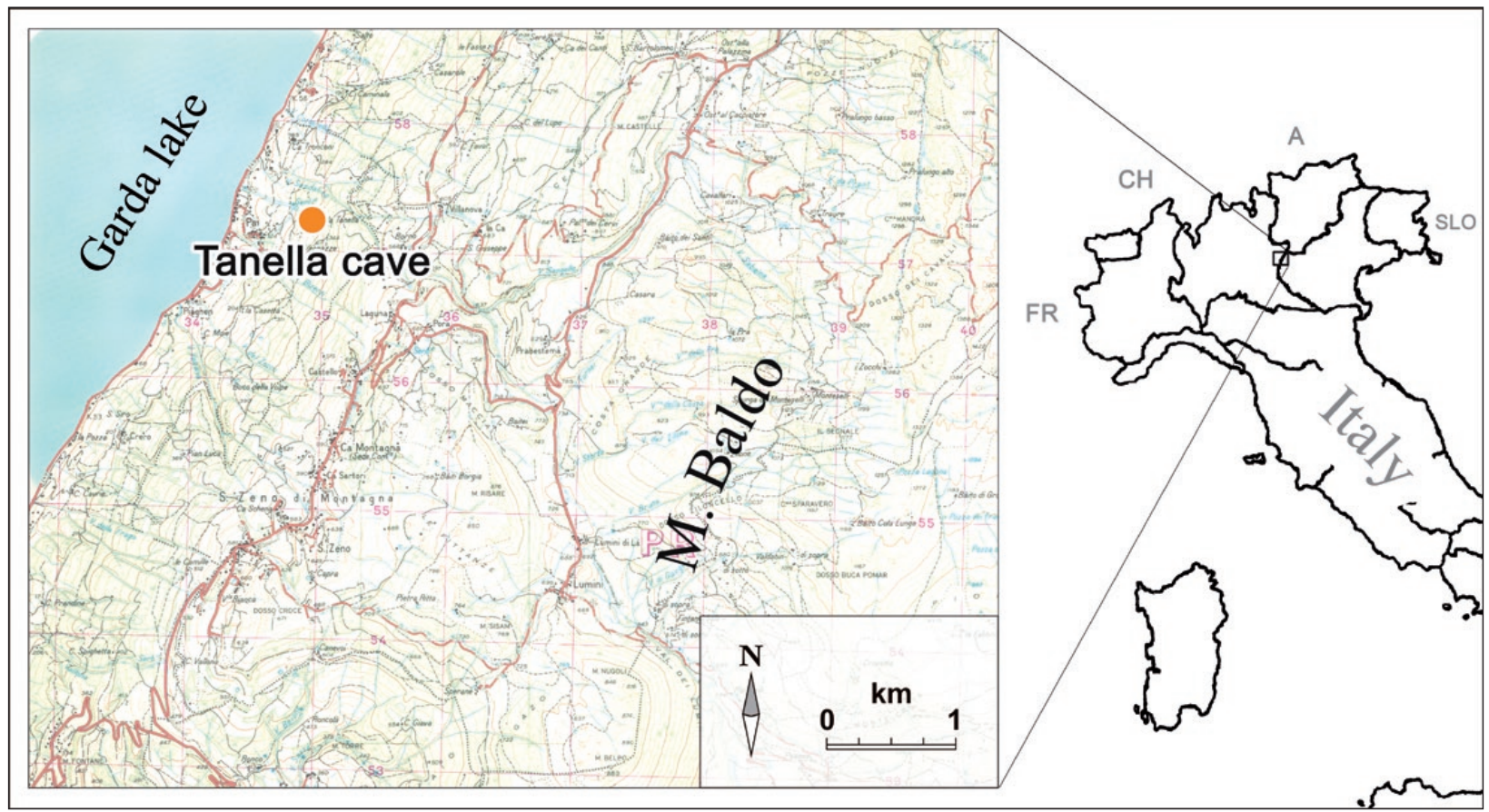

Fig. 1: Map showing location of the Tanella cave (Source: Istituto Geografico Militare, Tavoletta "Caprino Veronese”, 1969).

The purpose of the project is to reconstruct the evolution of the cavity during the last glaciation, to assess the chemical-physical and microbiological quality of the spring water and map out the hydrogeological basin of the spring for the purpose of safeguarding the water resource.

The cave has preserved fluvioglacial materials (pebbles, gravel, sand and varved silt) that are entirely similar to those of the periglacial surface environments (fluvial and fires, as well as about the provenance of pollen and micro-charcoals arrived into the cave. Besides some cave sediments, some control samples (mosses) were also analyzed to obtain recent pollen spectra useful to interpreting the past ones. The present study, performed on a few samples, is an assay, useful to attempt a first reconstruction and to decide, if it is advisable to go on with higher resolution analyses. 


\section{GEOMORPHOLOGICAL CLASSIFICATION}

The area of investigation is located on the west side of Monte Baldo. The chain of Monte Baldo is the westernmost pre-alpine mountains in the Veneto and extends from north-northeast to south-southwest, with many craggy peaks over 2,000 $\mathrm{m}$ a.s.l. (Fig. 2). The area of the crest has several glacial cirques facing west, from which the deep valleys, that go down towards the lake, originate. The main characteristic of this mountain is the coexistence of different morphologies, including tectonic, gravitational, karst, glacial, periglacial and fluvial, which testify to pronounced tectonic activity and the succession of clearly differentiated climatic phases. Typi-

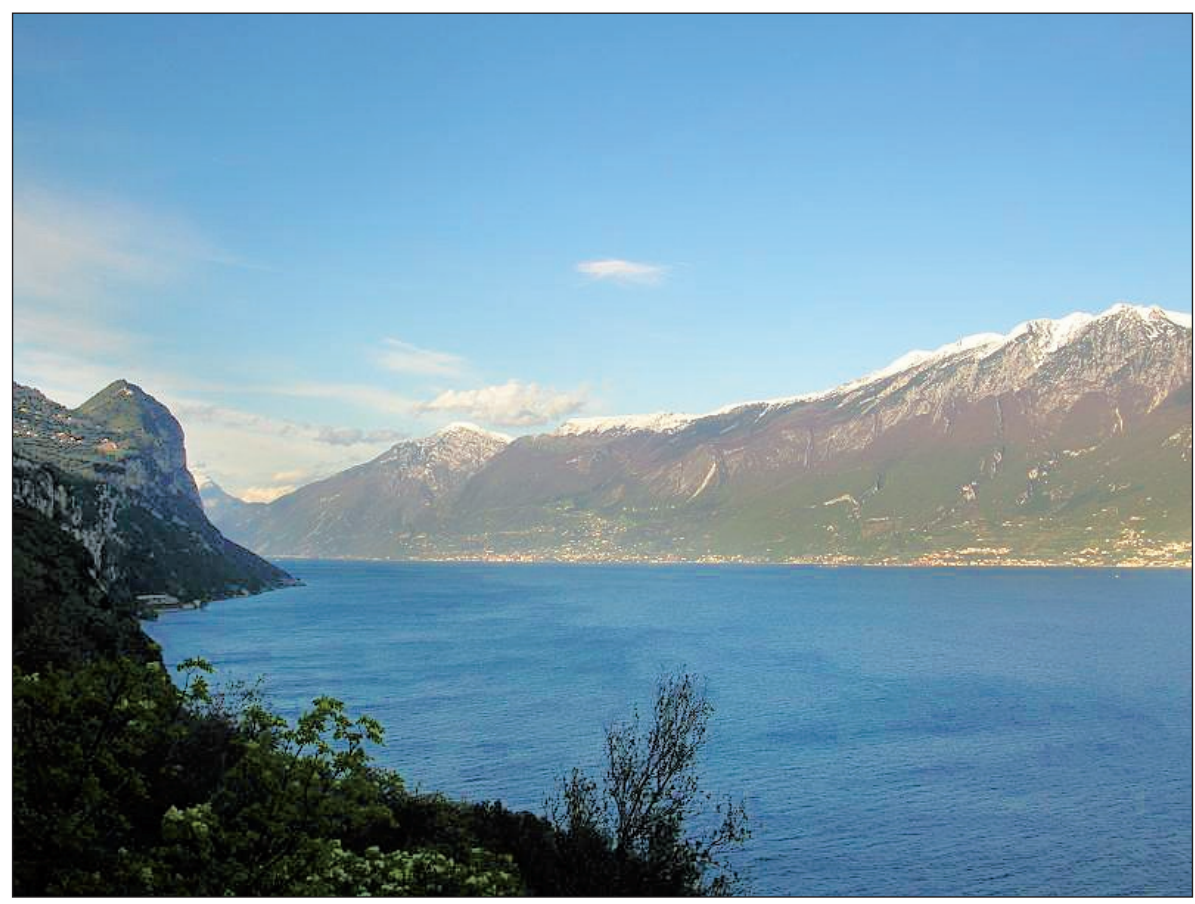

cal flatirons can be observed along the entire west side of Monte Baldo, due to the isolation of triangular portions of reef that have resisted to erosion within the ambit of the side of stratification, following the incision of gorges.

Much of the mountainside is also characterized by the absence of a hydrographic network worthy of note, which is activated only for brief temporary sections, following intense and prolonged precipitation. In the area surrounding the cave, where the covering of detritus and/ or the morainic covering have been recently eroded, the rocks appear to be rounded and the karst micro-forms are still in the embryonic stage or are completely absent, although they are quite evident locally. In fact, following the deglaciation of the Lake Garda glacier, which took place about 19,000 to 21,000 years ago (Monegato et al. 2007; Ferraro 2009), the karst phenomenon sculpted many characteristic forms, such as many forms of karren, etc. The result is a particular landscape where the forms of glacial erosion are superimposed by an extremely varied karst micro-landscape (Mietto \& Sauro 1989).

Fig. 2: Occidental side view of M. Baldo (Photo: R. Zorzin).

\section{GEOLOGICAL AND TECTONIC CLASSIFICATION}

The extended west side of Monte Baldo is the flank of an asymmetric fold, with a fault on the eastern side (Sauro \& Zampieri 1999), which coincides, on a large scale, with the stratification surfaces of the carbonate rocks of the Mesozoic units, which give rise to a monocline. These are mostly the lithotypes belonging to the Gruppo dei calcari Grigi, the Oolite di San Vigilio and the Rosso Ammonitico calcareous rocks. The Cretaceous and Cenozoic units have outcroppings on a more or less wide scale near Torri del Benaco, Malcesine and South of San Zeno di Montagna.
The Mesozoic and Paleogenic limestones are locally covered with loose or weakly cemented/dense deposits that can be ascribed to the Quaternary period, of glacial, fluvioglacial and alluvial origin. In particular, concerning the area around the Tanella cave, moderately to extremely dense morainic deposits have been observed. These materials may locally have a thickness of even more than $10 \mathrm{~m}$, with a pebble-gravel type of granulometry in a sandy-muddy matrix, with elements of local origin and elements originating from the Adige region. 
The area of investigation belongs to the southernmost portion of the South Alpine complex and is characterized today - and to a greater extent in the past - by compressive thrusts largely from South to North, which are responsible for the tectonic lifting of the pre-alpine area, especially starting from the Miocene (Castellarin et al. 1988). Local tectonics are influenced by the "Giudicarie Structural System", dominated by overlapping compressive morphostructures which run from northnortheast to south-southwest (Sauro \& Meneghel 1980). In the sector subject to this investigation, the stratifica- tion planes dips towards west-northwest at an inclination of $25^{\circ}-30^{\circ}$ and strata with a thickness ranging from a few decimeters to a few meters.

The presence of evident surface karst morphologies is definitely related to the nature of the outcropping lithotypes and to the manner of lifting, as well as to the succession of different landscapes and environments through the ages (Mietto \& Sauro 1989). In fact, the most important events in the geomorphological history of Monte Baldo are preserved in the shapes and deposits of several karst cavities, including the Tanella cave.

\section{DESCRIPTION OF THE CAVE}

The Tanella cave (Land Registry No. 79 V VR) opens on the west side of Monte Baldo and develops in the calcareous rocks of the S. Vigilio Oolite (Aalenian, lower Jurassic), which locally has a thickness of over $100 \mathrm{~m}$ (Roghi \& Romano 2008).

The spring cave has an extremely unique history. It was discovered in 1934 and on that occasion the first studies were undertaken by A. Pasa (1954).

Pietro Aloisi, a Pai habitant, thought to dig a gallery (1915-1919) in Tanella's cave, with the aim of intercepting a "big water lake", that should have to fill Tanella's spring; for unknown reasons the works were interrupted definitively in 1925.

The present-day cave is $392 \mathrm{~m}$ long and has two entrances (Ceradini 2002, 2004), a natural one that opens at $320 \mathrm{~m}$ a.s.l. and an artificial, which opens about 20 $\mathrm{m}$ lower (Fig. 3). The natural part develops for $210 \mathrm{~m}$ and starts with a large cave about $15 \mathrm{~m}$ long, which leads through a narrow passage, whose sides are marked by an evident tidal notch, to a second cave that has a strong gradient, where there are cemented pebbles and gravel, locally covered with calcite concretions. There are many stalactites on the vault, while the bottom of the cave contains two shafts, one that leads to the artificial gallery and the other near the deepest point, where the artificial gallery intercepts the phreatic passage. From this point, the cave extends for about $20 \mathrm{~m}$ with a slight upward grade and then for almost $40 \mathrm{~m}$, with a turn of about $20^{\circ}$, roughly following the levels of stratification, with a stupendous phreatic passage that has a semi-circular to elliptical shape, characterized by many large scallops and cupola along the walls and the vault and by a modest vadose channel on the floor. Various types of sediments have been preserved along this tract of the passage (gravel, sand, lime and clay), which once filled it completely. Near point 4 of the cave, four marked tidal notches can be observed at a height of about $25 \mathrm{~cm}$ and along the entire cross-section of the passage, whose heights can be traced to the emergence of the original siphon (today's natural entrance to the cave, which has also preserved a water level notch concretion) before it was intercepted by the artificial tunnel and emptied. From this point forward, the morphology of the passage, which continues its course, varies completely. It is narrow and high, with a rectangular section and a meandering course and is greatly conditioned by the structure with forms of differential dissolution, with beds and nodules of less soluble residual material. In the vicinity of the current limit of exploration the passage emerges through a shaft of about $6 \mathrm{~m}$, into a wider environment that develops upwards, with a $13 \mathrm{~m}$ high chimney (point 5 of the cave). It continues upwards from this point, along a rocky diaphragm, reaching a richly decorated and fully flooded room. This is a sump that was partially emptied recently along a vertical pit of about $20 \mathrm{~m}$, which leads to two small environments, followed by a slightly lowering conduit, which is partially blocked by sand and lime. This duct has been explored for over $15 \mathrm{~m}$ towards the north. At the base of the vertical shaft of the emptied sump, there is a beautiful calcite speleothem, which is partially hidden underneath the sand and which testifies to a vadose period of the karst circulation.

At least two levels of tectonic movement have been recognized along the artificial galleries, oriented from east to west and north to south, whose directions coincide perfectly with those of the development of the Tanella cave. These levels of "weakness" were almost definitely used by the subterranean waters and made the excavation of the artificial gallery easier. 


\section{HYDROGEOLOGY}

The Tanella spring is a perennial karst spring, whose flow has never been accurately measured. Although the cavity has a rather unique history and has aroused the interest of the local population, no studies of particular interest have been conducted. Pasa (1954) describes the cave as "very humid with a brook of variable flow running through it". Recent explorations and investigations carried out inside the cave have allowed us to increase our hydrogeological knowledge of the area surrounding the Tanella cave.

The hydrogeological basin of the Tanella spring is characterized by extensive outcroppings of calcareous rocks belonging to the S. Vigilio Oolite, upon which there are more or less powerful morainic deposits $(\mathrm{Fu}-$ ganti \& Panizza 1975). These calcareous rocks are able to absorb and return considerable volumes of water. The network of fractures involving the carbonate mass, along with the presence of morainic materials characterized by variable permeability, ranging from average to averagelow and by a high capacity for storage, thus constituting water resources of considerable importance.

The deep circulation of the water takes place primarily inside the fissured and karstified calcareous rocks of the S. Vigilio Oolite. Analysis and processing of data collected during the hydrogeological investigation, compared with the data collected on occasion of the test with tracers carried out on July $23^{\text {rd }}, 2009$ in the terminal siphon, have enabled us to get a sufficiently well defined hydrogeological picture. Sodium fluorescein $(350 \mathrm{~g})$ was used for dye tracing. The charcoal bags were positioned inside the cave, near the springs present below the cave,

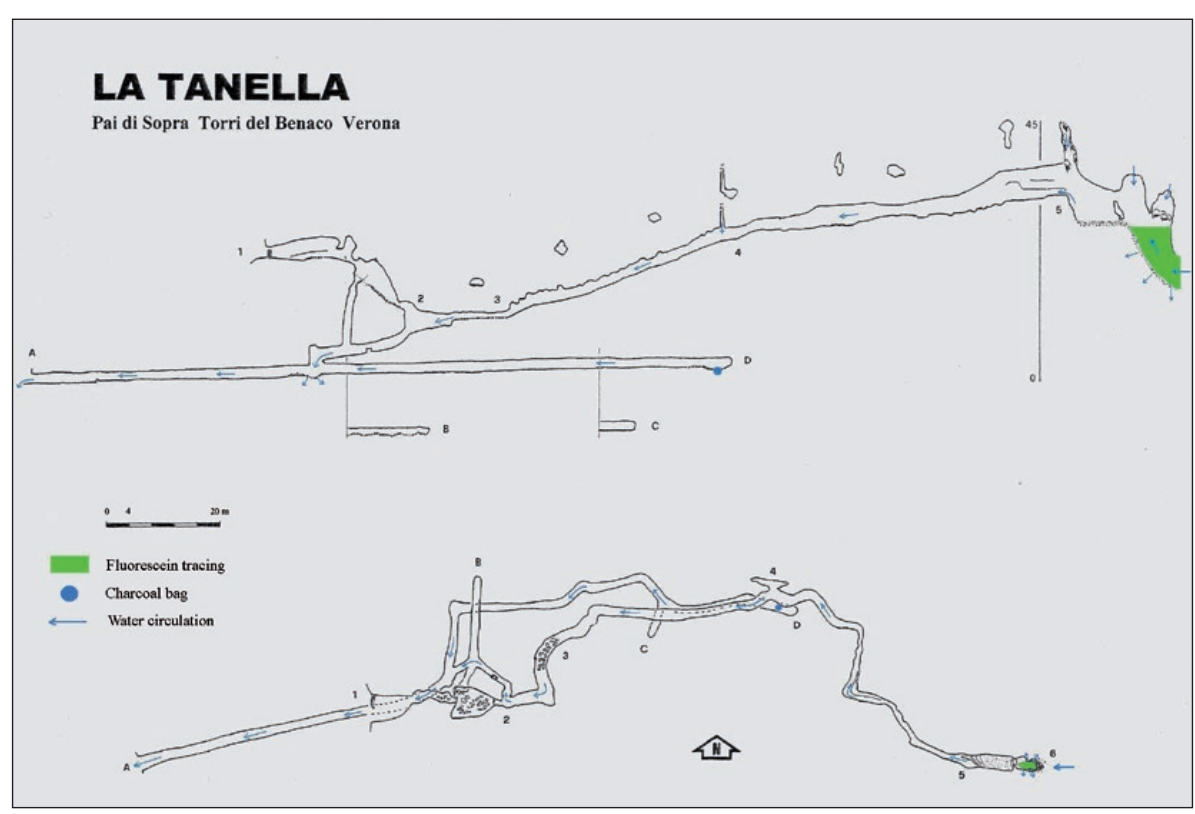

as well as in the Bizerti Valley and along the shore of Lake Garda (Figs. 3 and 4). The only positive charcoal bag, ten days after tracing, was the one located at the "Moscolo" spring, used by the "Camping ai salici" camp-

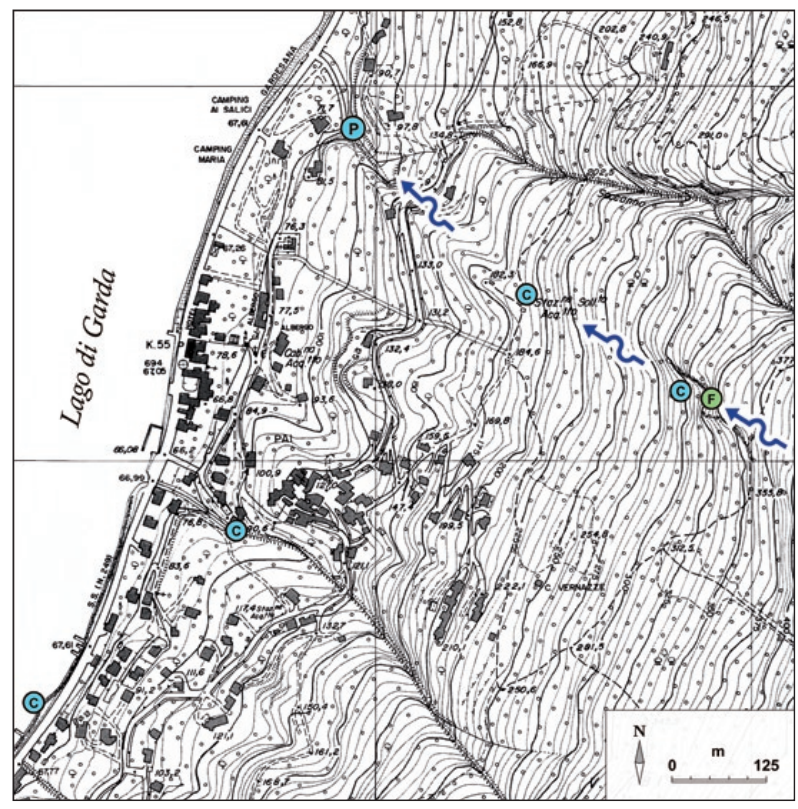

Fig. 4: Site of the tracing with sodic fluorescein $(F)$, of the charcoal bags $(C)$ and of the positive charcoal bag $(P)$. The groundwater flow circulation is indicated (Source: Carta Tecnica Regionale, Elemento n. 101092 "Pai", 1989).

ing ground. The positive reading of this charcoal bag and the variations in flow of the spring during emptying of the terminal sump of the Tanella, the flow drained off for drip-type irrigation and the variations in the phreatic level of the terminal sump during the emptying procedures carried out with an immersion pump, led to the hypothesis that the average natural losses in flow near the sump may be quantified in the amount of at least 50 liters per second. It cannot be excluded that most of these

Fig. 3: Map of the Tanella cave (Survey: Gruppo Attività Speleologica Veronese, Gruppo Speleologico Mantovano and Organizzazione Speleologica Modenese 27/09/03). 
losses feed one or more sub-lacustrine springs, which gush at short distance from the coastline.

Additionally, the information and observations collected allow us to assert that the aquifer that feeds the Tanella spring is characterized by a network with a heterogeneous flow. This aquifer consists of highly permeable areas that generally occupy very limited volumes (cavities, karst conduits, etc.) and wide sectors of rocky mass, characterized by a generally more reduced permeability (fractures, slightly karstified discontinuities, blocked and clogged karst conduits, etc.). The karst conduits present in the hydrogeological basin of the Tanella spring, on the basis of their position and organization in the carbonate aquifer of the west side of Monte Baldo, constitute preferential paths of underground flow.

On the basis of what we have asserted above, the Tanella spring is characterized by many interdependent drainage ways (interdependent drainage network) and a semi-dispersive circulation. In particular, this system is present in rocky masses with fracturing and other discontinuities, which are locally rather extensive and not very karstified. The unsaturated area is characterized by the absence of important water courses, while there is no lack of vertical cavities. These cavities are semi-active (having circulating water only in occasion of important and prolonged precipitation) and constitute preferential independent ways for the underground run-off towards the deeper areas of the aquifer. Near the altitude where the Tanella spring comes out, in correspondence a variation of permeability or a decrease in the absorbent fracture, there is a saturated area, characterized by an interconnected series of variously karstified conduits and fractures, which constitute an important reservoir containing large hydrogeological reserves. Probably, this is an area involved by the presence of a close series of dislocations with a small throw, like the ones intercepted by the artificial gallery.

The fracturing and karstification of the carbonate mass containing the aquifer of the Tanella spring and the local covering of morainic deposits considerably affect the flow. In fact, even following abundant precipitation, the flow shows smaller variations and a delayed response. Near the karst network, water levels may show even strong variations in height following the arrival of important volumes of newly infiltrated water and the impossibility of the main drainage ways to drain off the great water flow rapidly. Currently, the cave functions as an "overflow". The information gathered in the field confirms that the spring is subject to periodical and considerable floods (Ceradini 2004). The local inhabitants remember serious floods till about the first 60 's. Afterwards, no particular events have been reported even if often a water circulation is present in the phreatic passage and in the artificial one.

The hydrogeochemical indicators also show temporary abnormal variations in mineralization during and outside the floods, which lead to the hypothesis that the system feeding the Tanella spring must be characterized

Tab. 1: Chemical and microbiological analyses of the water.

\begin{tabular}{|c|c|c|c|c|c|c|c|c|c|c|c|}
\hline Date (2009) & & $15 / 02$ & $25 / 02$ & $05 / 03$ & $18 / 03$ & $29 / 03$ & $12 / 07$ & $23 / 07$ & $26 / 07$ & $30 / 07$ & $02 / 08$ \\
\hline Aspect & & limp. & limp. & limp. & limp. & limp. & limp. & limp. & limp. & limp. & limp. \\
\hline Temp $20^{\circ} \mathrm{C}$ water & ${ }^{\circ} \mathrm{C}$ & 9.8 & 9.8 & 9.9 & 9.8 & 9.9 & 10.7 & 11.0 & 11.0 & 11.2 & 11.2 \\
\hline $\mathrm{pH}$ & & 7.81 & 7.70 & 8.21 & 7.45 & 7.71 & 7.8 & 7.7 & 8.0 & 7.8 & 7.7 \\
\hline Conductivity To $20^{\circ} \mathrm{C}$ & $\mu \mathrm{S} / \mathrm{cm}$ & 301 & 316 & 201 & 403 & 335 & 254 & 331 & 498 & 402 & 361 \\
\hline Alkalinity tot. & $\mathrm{meq} / \mathrm{l}$ & 3.3 & 3.4 & 2.4 & 4.7 & 4.8 & & & & & \\
\hline Hardness & ${ }^{\circ} \mathrm{F}$ & 19.7 & 18 & 11.4 & 21.5 & 22.5 & 15 & 21 & 20 & 20 & 18 \\
\hline Nitrate & $\mathrm{mg} / \mathrm{l}$ & & 2 & 2 & 2 & 5 & 2 & 5 & 5 & 5 & 2 \\
\hline Nitrite & $\mathrm{mg} / \mathrm{l}$ & 0.005 & 0.012 & & 0 & 0.005 & & & & & \\
\hline Ammonium & $\mathrm{mg} / \mathrm{l}$ & 0.050 & 0.050 & 0 & 0.05 & 0 & & & & & \\
\hline Chloride & $\mathrm{mg} / \mathrm{l}$ & 10.9 & 3.9 & 4.9 & 3.3 & 4.6 & & & & & \\
\hline Oxidisability (Kubel) & $\mathrm{mg} \mathrm{O}_{2} / \mathrm{I}$ & 1.3 & 1.1 & 3.0 & 0.9 & 1.4 & & & & & \\
\hline Iron & $\mu \mathrm{g} / \mathrm{l}$ & 80 & 20 & 0 & 10 & 30 & & & & & \\
\hline Phosphorus & $\mathrm{mg} / \mathrm{l}$ & 0.9 & 0 & 0.27 & 0 & 0.09 & & & & & \\
\hline Fixed residue & $\mathrm{mg} / \mathrm{l}$ & 200 & 210 & 154 & 230 & 251 & & & & & \\
\hline Coliforms tot. & $\mathrm{ufc} / 100 \mathrm{ml}$ & & & 1225 & & & 75 & 70 & 182 & 137 & 158 \\
\hline Fecal Coliforms & $\mathrm{ufc} / 100 \mathrm{ml}$ & & & 1140 & & & & & & & \\
\hline Faecal Streptococci & $\mathrm{ufc} / 100 \mathrm{ml}$ & & & 16 & & & & & & & \\
\hline Salmonella & & & & 0 & & & & & & & \\
\hline Escherichia coli & $\mathrm{ufc} / 100 \mathrm{ml}$ & & & & & & 1 & 0 & 2 & 2 & 3 \\
\hline
\end{tabular}


by the presence of several complex sumps, located near the limit of the hydrogeological structure.

Several chemical and microbiological water analyses were carried out directly in the field, as well as additional, more precise and complete at the laboratory analyses. The results of these analyses, which were carried out between February and March of 2009 (Tab. 1 and Fig. 2), show that the parameters are between categories A1 and A2; namely, this water is characterized by

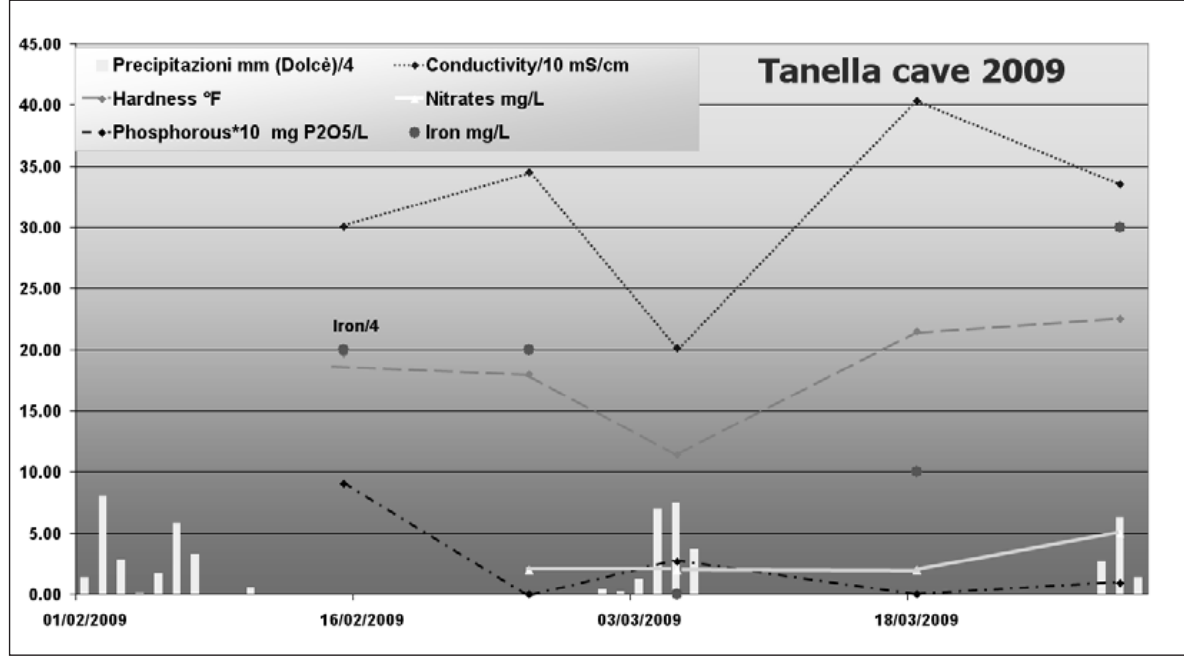

Fig. 5: Variations of some chemical parameters with the precipitations.

modest organic pollution and may be used for drinking water purposes only after normal physical and chemical treatment and disinfection. The temperature of the wa- ter, taken near the sump, was quite constant during the period of observation and was between $9.8^{\circ}$ and $11.2^{\circ} \mathrm{C}$.

Possible future catchment of the Tanella spring water for drinking purposes should be preceded by a series of tests with tracers to confirm the extension of the hydrogeological basin, which has currently based only on the geological data gathered in the field. In fact, the tracing (Ceradini \& De Angeli 2007) at Spluga dei Cervi, ascertained the hydrogeological connection with the San

Zeno spring, located $3 \mathrm{~km}$ north of Tanella. This tracing allows us to exclude Spluga dei Cervi and M. Castello areas' from the hydrogeological basin of the Tanella spring. In fact, the current hydrogeological basin of the Tanella spring has been identified in the territory to the east and southeast of the cave, in altitudes below 700 $\mathrm{m}$ a.s.l. In the past, on the other hand, it is quite possible that the hydrogeological basin was quite a bit larger and included at least part of Vajo Sengello, north of Palazzo dei Cervi and part of the large karst depression between Prabestemà and Baitiei, where several sinkholes must have been active.

\section{POLLEN AND MICRO-CHARCOALS}

\section{METHODS}

Pollen - eight samples were collected in 2008, as follows: a) five sediment samples from the cave, four of which taken along a $140 \mathrm{~cm}$ thick sequence (samples $1,2,3,4$; sample 4 is the lowest one; sample 5 at ca. 60 $\mathrm{cm}$ from the sequence, at the same depth as sample 1 (Fig. 6); b) three control samples (mosses: samples 6, 7,8 ); samples 6 and 7 were collected near the cave, the first near its lower, artificial entrance and the second near the higher, natural entrance; sample 8 was collected about $3 \mathrm{~km}$ far from the cave, at $937 \mathrm{~m}$ a.s.l. Samples (about 1 - $15 \mathrm{~g}$ dry weight) were treated with a routine method: tetra-Na-pyrophosphate, $\mathrm{HCl} 10 \%$, acetolysis, heavy liquid separation (Na-metatungstate hydrate), HF $40 \%$, ethanol 98\%. Lycopodium spore tablets were added to calculate pollen concentration (pollen grains per gram $=\mathrm{p} / \mathrm{g}$ ). Slides were mounted in glycerol jelly and closed with paraffin. Analysis was carried out at light microscope at 1,000 magnifications. Pollen identification was based on the reference type pollen collection, current atlases and keys (e.g., Andersen 1979; Beug 1961; Faegri \& Iversen 1989; Moore et al. 1991; Punt 1976; Punt \& Clarke 1980 - 1991; Punt et al. 19952009; Reille 1992-1998). Percentage pollen spectra were calculated in two ways, one including total pollen (Tab. 2) and the other only pollen of woody plants (not reported here). Syntethic pollen graphics (Fig. 7) are reported. Percentage values quoted in the text without any comment are based on total pollen. The basic pollen terminology refers to Berglund \& Ralska Jasiewiczowa 1986; pollen type names refer to the relevant pollen keys and plant names to Pignatti 1982. The terms 
"cf.", "type", "group", are omitted in the text. They are reported in pollen spectra (Tab. 2).

Micro-charcoals - The analysis was carried out according to Torri et al. 2009, where particles are divided in 5 classes based on their maximum diameter: Class 1: > $250 \mu \mathrm{m}$; Class 2: 125-250 $\mu \mathrm{m}$; Class 3: 50-125 $\mu \mathrm{m}$; Class 4: 10-50 $\mu \mathrm{m}$; Class 5: $<10 \mu \mathrm{m})$.

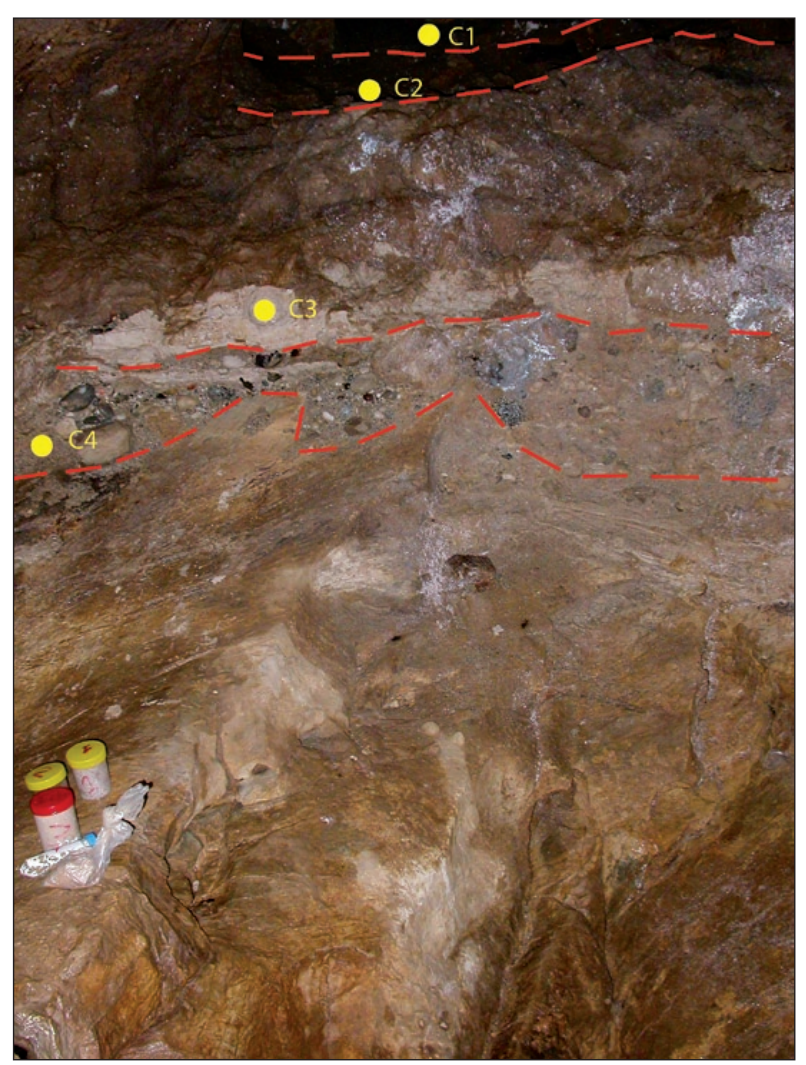

Fig. 6: Sequence of pollen samples in the Cave. C1: slightly cemented gravel, cobblestones, sand, silt and reddish-brown clay; C2: nut-brown silt and reddish-brown clay; C3: silt with very thin layers of sand and gravel; C4: gravel, sand and cobblestones (Photo: R. Zorzin).

\section{CHRONOLOGY}

Because of the low number of samples, strict correlations with relevant data in literature concerning the area could not be made (Bartolomei et al. 1982, 1987-1988; Bertoldi 1968; Beghè 2008; Bertoldi \& Andreolli 1977; Cattani 1976, 1990; Conedera et al. 2004; Paganelli 1984; Ravazzi 2005; Sorbini et al. 1984). Anyway, as Tanella cave pollen shows a coherent succession, matching the main features of the vegetation history of the area, broad hypotheses of chronology were attempted.

\section{RESULTS AND DISCUSSION ON POLLEN ANALYSIS}

Pollen - Concentration varies from very low - high $\left(10^{1}\right.$ $10^{5} \mathrm{p} / \mathrm{g}$ ) in the cave samples, to very high in the mosses $\left(10^{5}-10^{6} \mathrm{p} / \mathrm{g}\right)$. Preservation is good - very good (Fig. 8), except in sample 2, where also badly preserved pollen grains were found. Corroded, degraded pollen was observed, suggesting biochemical and chemical oxidation under aerial and subaerial conditions (Berglund \& Ralska Jasiewiczowa 1986).

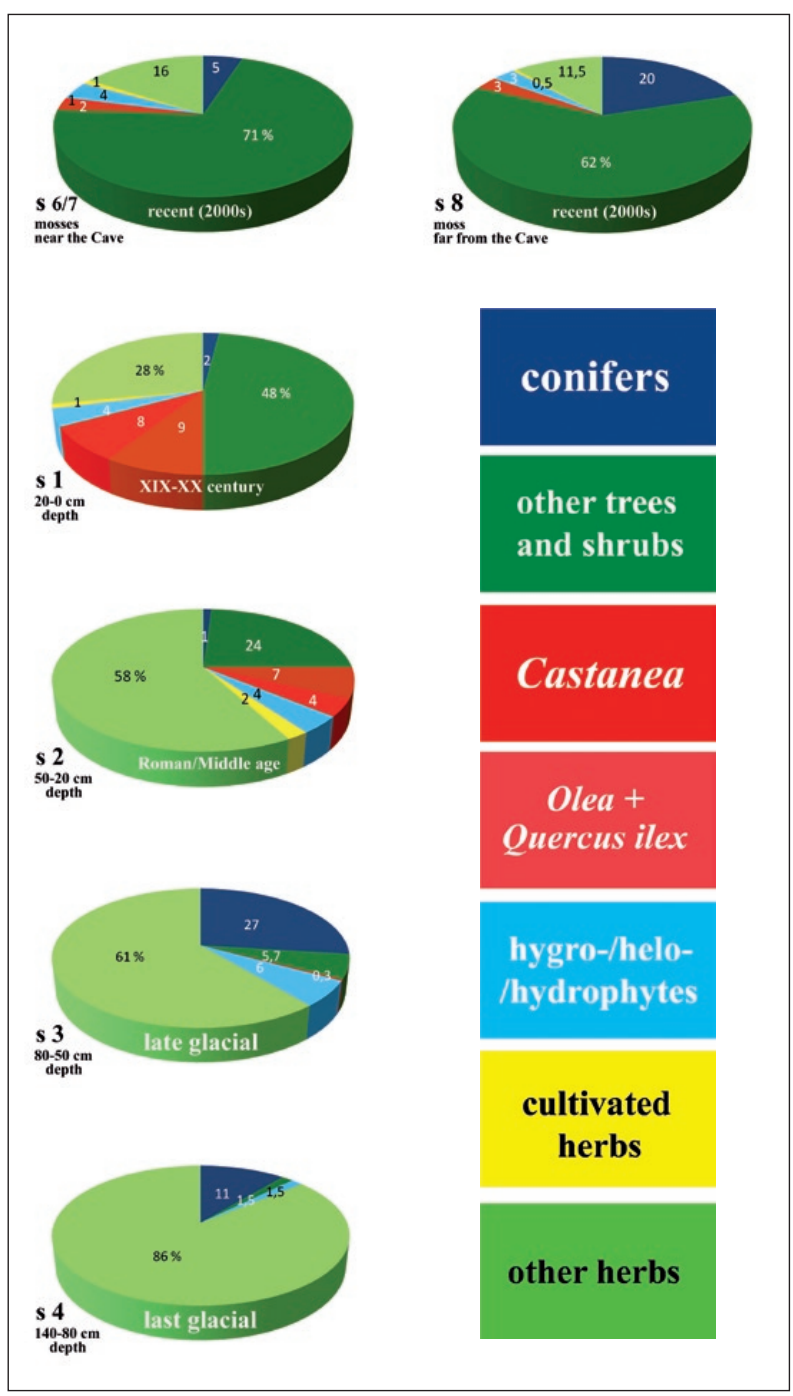

Fig. 7: Syntethic pollen graphics.

The pollen flora is quite rich: ca. 30 taxa were identified. While pollen flora of samples is quite similar, vegetation shows differences.

Micro-charcoals - Total concentration is notably variable in cave samples $\left(10^{1}-10^{5} \mathrm{~m} / \mathrm{g}\right)$ and always high in mosses $\left(10^{6} \mathrm{~m} / \mathrm{g}\right)$. Small-sized particles (classes $\left.3,4,5\right)$ are 
Tab. 2: Pollen spectra.

\begin{tabular}{|c|c|c|c|c|c|c|c|c|c|}
\hline \multicolumn{10}{|c|}{ Tanella cave (Torri del Benaco - Verona - Italy) } \\
\hline \multicolumn{2}{|l|}{ Pollen samples } & 4 & 3 & 2 & 1 & 5 & 6 & 7 & 8 \\
\hline \multicolumn{2}{|l|}{ Depth (cm) } & 120 & 65 & 25 & 10 & 10 & $\begin{array}{c}\text { moss } \\
\text { near the } \\
\text { cave lower } \\
\text { entrance }\end{array}$ & $\begin{array}{c}\text { moss } \\
\text { near the } \\
\text { cave higher } \\
\text { entrance }\end{array}$ & $\begin{array}{c}\text { moss } \\
\text { ca. } 3 \mathrm{~km} \\
\text { far from } \\
\text { the cave }\end{array}$ \\
\hline \multicolumn{2}{|c|}{ POLLEN CONCENTRATION } & 78 & 129 & 2938 & 1240 & 1204 & 1025094 & 5405073 & 466049 \\
\hline \multicolumn{2}{|c|}{ POLLEN SUM } & 295 & 210 & 534 & 551 & 502 & 818 & 577 & 755 \\
\hline \multicolumn{10}{|c|}{ TREES + SHRUBS + LIANES } \\
\hline ACERACEAE & Acer campestre type & & 0.5 & & & & & & 1.1 \\
\hline ANACARDIACEAE & Pistacia cf. P. terebinthus L. & & & & 0.2 & & 2.4 & 1.6 & \\
\hline AQUIFOLIACEAE & Ilex aquifolium $L$. & & & 0.2 & & & & & \\
\hline ARALIACEAE & Hedera helix L. & & & 0.4 & & & 0.2 & & \\
\hline BETULACEAE & Alnus undiff. & & & & & & 1.1 & 1.6 & \\
\hline$"$ & Alnus cf. A. incana (L.) Moench & & 0.5 & & & & & & 0.3 \\
\hline$"$ & Alnus cf. A. glutinosa (L.) Gaertner & & 0.5 & 0.6 & 0.4 & 0.4 & & & 0.8 \\
\hline " & Alnus cf. A. viridis (Chaix) DC. & & 0.5 & & & & & & \\
\hline$"$ & Betula & 0.3 & 1.0 & 0.6 & 2.0 & 1.6 & 1.5 & 2.1 & 5.3 \\
\hline CANNABACEAE & Humulus lupulus $L$. & & & & 0.2 & 0.6 & 0.2 & 0.3 & 0.5 \\
\hline CAPRIFOLIACEAE & Sambucus nigra L. & & & & 0.2 & 0.2 & & & \\
\hline$"$ & Sambucus racemosa $L$. & 0.3 & & & 0.4 & 0.2 & & & \\
\hline$"$ & Viburnum cf. V. Iantana L. & & & & 0.5 & 0.2 & 0.2 & & \\
\hline CISTACEAE & $\begin{array}{l}\text { Helianthemum cf. H. nummularium (L.) } \\
\text { Miller }\end{array}$ & & & 0.2 & & & & & \\
\hline CORNACEAE & Cornus mas $L$. & & & & & & 0.4 & & 0.5 \\
\hline CORYLACEAE & Corylus avellana $\mathrm{L}$. & 0.3 & & 0.7 & 1.6 & 1.4 & 4.6 & 6.8 & 24.1 \\
\hline " & Carpinus betulus $L$. & & 0.5 & 0.4 & 0.5 & 0.4 & 0.2 & & 0.3 \\
\hline " & Carpinus orientalis Miller & & & & 5.4 & 2.2 & 3.3 & 2.4 & 0.5 \\
\hline " & Ostrya carpinifolia Scop. & 0.3 & 1.0 & 0.4 & 12.0 & 17.5 & 25.3 & 26.9 & 11.9 \\
\hline CUPRESSACEAE & Cupressaceae cf. Thuja & & & & & & 1.3 & 0.9 & 0.1 \\
\hline$"$ & exotic Cupressaceae undiff. & & & & & & 0.9 & 0.3 & 1.1 \\
\hline " & Juniperus type & 2.0 & & 0.9 & 0.9 & 0.8 & 2.0 & 2.1 & 1.6 \\
\hline ERICACEAE & Calluna vulgaris $L$. & & & 17.4 & 0.4 & & & & 0.3 \\
\hline$" \prime$ & Erica & & & 0.4 & 0.4 & & & & \\
\hline FAGACEAE & Castanea sativa Miller & & & 7.3 & 8.9 & 5.0 & 2.6 & 1.7 & 3.3 \\
\hline " & Fagus sylvatica $L$. & & & 0.2 & & 0.2 & & & 2.0 \\
\hline$"$ & Quercus cf. Q. cerris L. & & & & 1.3 & 0.2 & & & 1.3 \\
\hline$"$ & Quercus decidua undiff. & 0.3 & 1.0 & 2.4 & 3.3 & 5.6 & 5.3 & 9.7 & 7.3 \\
\hline$"$ & Quercus ilex L. & & 0.5 & 1.5 & 4.2 & 3.8 & 0.4 & 0.2 & \\
\hline$"$ & Quercus cf. Q. pubescens Willd. & & 0.5 & 0.6 & 3.4 & 3.8 & 1.3 & 1.6 & 0.9 \\
\hline$"$ & Quercus cf. Q. robur L. & & & & 0.9 & 0.4 & & & \\
\hline JUGLANDACEAE & Juglans regia $L$. & & & & 0.2 & 0.6 & 0.4 & 0.9 & 1.5 \\
\hline LEGUMINOSAE & Cytisus & & & & 0.2 & & & & 0.3 \\
\hline$"$ & Genista & & & 0.6 & & & & & \\
\hline MORACEAE & Morus alba L. & & & & & & 0.7 & & \\
\hline OLEACEAE & Fraxinus cf. F. excelsior L. & & 0.5 & & 0.5 & 0.2 & & & 1.7 \\
\hline " & Fraxinus ornus $L$. & 0.3 & & 0.7 & 12.3 & 13.9 & 19.8 & 15.6 & 1.1 \\
\hline$"$ & Olea europea L. & & & 2.2 & 4.0 & 3.2 & 1.3 & 0.5 & 0.1 \\
\hline$"$ & Phillyrea & & & & & & & & \\
\hline PINACEAE & Abies alba Miller & & & 0.2 & & & & & 0.8 \\
\hline$"$ & Cedrus & & & & & 0.2 & 0.2 & 0.5 & 1.1 \\
\hline$"$ & Larix decidua Miller & 0.7 & & & & & & & 1.1 \\
\hline$"$ & exotic Picea & & & & & & 0.2 & 0.5 & 1.5 \\
\hline$"$ & Picea excelsa (Lam.) Link & & & & & & & & 5.0 \\
\hline$"$ & Pinus undiff. & 1.7 & & 0.2 & 0.7 & 1.4 & 0.9 & 0.9 & 1.3 \\
\hline$"$ & exotic Pinus & & & & & & & & 0.7 \\
\hline$"$ & Pinus cembra L. & 0.7 & 1.9 & & & & & & \\
\hline$"$ & Pinus cf. P. pinea L. & & & & 0.2 & & & & \\
\hline$"$ & Pinus mugo Turra & 3.4 & 7.1 & & & & & & 0.3 \\
\hline
\end{tabular}




\begin{tabular}{|c|c|c|c|c|c|c|c|c|c|}
\hline \multicolumn{10}{|c|}{ Tanella cave (Torri del Benaco - Verona - Italy) } \\
\hline \multicolumn{2}{|l|}{ Pollen samples } & 4 & 3 & 2 & 1 & 5 & 6 & 7 & 8 \\
\hline \multicolumn{2}{|l|}{ Depth (cm) } & 120 & 65 & 25 & 10 & 10 & $\begin{array}{c}\text { moss } \\
\text { near the } \\
\text { cave lower } \\
\text { entrance }\end{array}$ & $\begin{array}{c}\text { moss } \\
\text { near the } \\
\text { cave higher } \\
\text { entrance }\end{array}$ & $\begin{array}{c}\text { moss } \\
\text { ca. } 3 \mathrm{~km} \\
\text { far from } \\
\text { the cave }\end{array}$ \\
\hline \multicolumn{2}{|c|}{ POLLEN CONCENTRATION } & 78 & 129 & 2938 & 1240 & 1204 & 1025094 & 5405073 & 466049 \\
\hline \multicolumn{2}{|l|}{ POLLEN SUM } & 295 & 210 & 534 & 551 & 502 & 818 & 577 & 755 \\
\hline " & Pinus sylvestris $L$. & 2.4 & 17.6 & & 0.4 & 0.4 & & & 5.3 \\
\hline PLATANACEAE & Platanus cf. P. hybrida Brot. & & & & & & 0.2 & 0.9 & 0.9 \\
\hline RHAMNACEAE & Frangula alnus Miller & & & 0.2 & 0.2 & 0.4 & 0.4 & 0.7 & \\
\hline RANUNCULACEAE & Clematis & & 0.5 & & 0.4 & 0.2 & & & \\
\hline ROSACEAE & Prunus avium L. & & & & & & 0.2 & 0.3 & 0.4 \\
\hline " & Prunus & & 0.5 & & & & & & \\
\hline " & Rubus & & 0.5 & & & & & & \\
\hline SALICACEAE & Populus & & 0.5 & & 0.5 & 0.6 & 0.4 & 1.6 & 0.8 \\
\hline " & Salix & & 0.5 & & 1.8 & 2.0 & 0.4 & 1.9 & 0.4 \\
\hline TILIACEAE & Tilia cf. T. cordata Miller & 0.3 & & & 0.4 & 0.2 & & & 0.5 \\
\hline ULMACEAE & Ulmus & & & & 0.4 & 0.2 & 0.4 & 0.9 & \\
\hline VITACEAE & Vitis vinifera $L$. & & & & 0.7 & 0.2 & 1.3 & 1.6 & 0.1 \\
\hline \multicolumn{2}{|c|}{ TREE + SHRUB + LIANE SUM } & 13.2 & 35.7 & 38.2 & 69.9 & 68.1 & 80.4 & 84.7 & 87.9 \\
\hline \multicolumn{10}{|c|}{ HERBS } \\
\hline ALISMATACEAE & Alisma cf. A. plantago-aquatica L. & & 0.5 & 0.2 & & & & & \\
\hline$"$ & Sagittaria & & 0.5 & & & & & & \\
\hline CAMPANULACEAE & Campanula & 0.7 & & & & 0.2 & & & \\
\hline CANNABACEAE & Cannabis & & & & 0.2 & & & & \\
\hline CAPRIFOLIACEAE & Sambucus ebulus $L$. & & & & 0.4 & & & & \\
\hline CARYOPHYLLACEAE & Caryophyllaceae undiff. & & & 0.4 & & & & & 0.5 \\
\hline " & Herniaria & & & 0.4 & & & & & \\
\hline CHENOPODIACEAE & Chenopodiaceae undiff. & 1.0 & & & & & & & \\
\hline 4 & Beta cf. B. vulgaris L. & & & 0.4 & & & & & \\
\hline " & Chenopodiaceae cf. Chenopodium & & & 0.2 & 2.2 & 1.8 & 0.4 & & \\
\hline COMPOSITAE & Anthemis type & & 0.5 & & & & & & 0.3 \\
\hline$"$ & Ambrosia & & & & 0.4 & & & & \\
\hline$"$ & Artemisia & 1.0 & 8.6 & 0.4 & & & & & \\
\hline " & Aster type & 1.0 & 1.9 & 0.2 & 0.5 & & & & \\
\hline$"$ & Compositae cf. Carduus & 0.7 & 0.5 & & & & & & \\
\hline " & Centaurea nigra type & 0.7 & 1.9 & 0.9 & 0.4 & 0.2 & & 0.3 & \\
\hline$"$ & Cichorioideae undiff. & 50.2 & 13.3 & 21.9 & 3.8 & 7.0 & & & 1.5 \\
\hline " & Echinops & & 0.5 & & & & & & \\
\hline$"$ & Matricaria & & & & 0.4 & & & & 0.3 \\
\hline CONVOLVULACEAE & Convolvulus arvensis $L$. & & & 0.2 & & & & & \\
\hline CRASSULACEAE & Sedum & & & 0.2 & & & & & \\
\hline CRUCIFERAE & Hornungia type & 2.7 & & 0.6 & 0.5 & & & 1.0 & \\
\hline " & Sinapis type & & & & & & & & 0.3 \\
\hline CYPERACEAE & Eriophorum & & 0.5 & & & & & & \\
\hline$"$ & Carex & & & 0.2 & & & & 0.3 & 0.3 \\
\hline GRAMINEAE & Avena-Triticum group & & & 0.7 & 0.2 & & 0.4 & 0.3 & 0.5 \\
\hline$"$ & Cerealia undiff. & & & & & & & & \\
\hline " & wild Gramineae group & 21.0 & 21.4 & 23.4 & 13.8 & 14.9 & 11.9 & 6.8 & 4.2 \\
\hline$"$ & Hordeum group & & & 0.6 & 0.9 & 0.8 & 0.2 & 0.2 & \\
\hline$"$ & Triticum & & & 0.4 & & & 0.2 & & \\
\hline$"$ & Phragmites australis Adanson & & 1.0 & 2.8 & 0.7 & 1.0 & 0.2 & & 0.1 \\
\hline$"$ & Secale cereale L. & & & & 0.2 & & & & \\
\hline GUTTIFERAE & Hypericum & & 0.5 & & 0.2 & & 0.4 & & \\
\hline LABIATEAE & Mentha type & & & 0.6 & & & 0.7 & & 0.5 \\
\hline$"$ & Teucrium & & & 0.2 & & & & & \\
\hline HALORAGACEAE & Myriophyllum & 0.3 & 0.5 & & 0.2 & 0.8 & & & \\
\hline LEGUMINOSAE & Leguminosae undiff. & & & 0.4 & & 0.2 & & & 0.3 \\
\hline$"$ & Lotus & 0.3 & 0.5 & & 0.2 & & 0.2 & & 0.3 \\
\hline
\end{tabular}




\begin{tabular}{|c|c|c|c|c|c|c|c|c|c|}
\hline \multicolumn{10}{|c|}{ Tanella cave (Torri del Benaco - Verona - Italy) } \\
\hline \multicolumn{2}{|l|}{ Pollen samples } & 4 & 3 & 2 & 1 & 5 & 6 & 7 & 8 \\
\hline \multicolumn{2}{|l|}{ Depth (cm) } & 120 & 65 & 25 & 10 & 10 & $\begin{array}{c}\text { moss } \\
\text { near the } \\
\text { cave lower } \\
\text { entrance }\end{array}$ & $\begin{array}{c}\text { moss } \\
\text { near the } \\
\text { cave higher } \\
\text { entrance }\end{array}$ & $\begin{array}{c}\text { moss } \\
\text { ca. } 3 \mathrm{~km} \\
\text { far from } \\
\text { the cave }\end{array}$ \\
\hline \multicolumn{2}{|c|}{ POLLEN CONCENTRATION } & 78 & 129 & 2938 & 1240 & 1204 & 1025094 & 5405073 & 466049 \\
\hline \multicolumn{2}{|l|}{ POLLEN SUM } & 295 & 210 & 534 & 551 & 502 & 818 & 577 & 755 \\
\hline LEMNACEAE & Lemna & 0.3 & & 0.4 & & & & & 0.1 \\
\hline LILIACEAE & Liliaceae undiff. & & & & & & 0.2 & 0.7 & \\
\hline$"$ & Allium & & & & & & & 0.3 & \\
\hline ONAGRACEAE & Circaea & 0.7 & & & & & & & \\
\hline PAPAVERACEAE & Papaver cf. P. rhoeas L. & & & 0.6 & & & & & \\
\hline PLANTAGINACEAE & Plantago undiff. & 1.7 & 2.4 & & 0.4 & 0.8 & 1.5 & 1.9 & 0.7 \\
\hline$"$ & Plantago lanceolata $L$. & & & 2.6 & 1.1 & 1.8 & 1.5 & & \\
\hline$"$ & Plantago major L. & & & & 0.7 & & & & \\
\hline PLUMBAGINACEAE & Armeria & 0.3 & & & & & & & \\
\hline POLYGONACEAE & Rumex & & 1.0 & & & & 0.9 & 1.2 & 0.3 \\
\hline POTAMOGETONACEAE & Potamogeton & & & & 0.4 & & & & \\
\hline PRIMULACEAE & Androsace & 0.3 & & & & 0.2 & & & \\
\hline RANUNCULACEAE & Anemone cf. A. nemorosa L. & & & & 0.4 & 0.2 & & & \\
\hline$"$ & Aquilegia & & 1.0 & & & & & & \\
\hline$"$ & Caltha palustris $L$. & & 0.5 & & & & & & \\
\hline$"$ & Ranunculus type & 0.6 & & 0.4 & & & 0.4 & & 0.7 \\
\hline " & Thalictrum & & & & & & & & 0.3 \\
\hline ROSACEAE & Rosaceae undiff. & & & 0.2 & & 0.4 & 0.2 & & \\
\hline " & Alchemilla type & & 0.5 & 0.2 & & & & & \\
\hline$"$ & Filipendula & & 0.5 & 0.4 & & 0.4 & 0.2 & 0.5 & \\
\hline " & Geum & & 0.5 & & & & & & \\
\hline$"$ & Potentilla & & 1.4 & & & & & & \\
\hline RUBIACEAE & Galium type & & 0.5 & 0.2 & & & & & 0.3 \\
\hline SAXIFRAGACEAE & Parnassia palustris $L$. & 0.3 & & & & & & & \\
\hline$"$ & Saxifraga & 0.3 & 0.5 & & & & & & \\
\hline SCROPHULARIACEAE & Euphrasia & & & & & & 0.2 & & \\
\hline$"$ & Scrophularia & 0.3 & 0.5 & 0.2 & & & & & 0.3 \\
\hline$"$ & Linaria & 1.0 & 1.4 & 0.2 & & & & & 0.3 \\
\hline$"$ & Melampyrum & & 0.5 & & & & & & \\
\hline " & Verbascum & & & & & & & 0.5 & \\
\hline TYPHACEAE & Typha angustifolia type & & 0.5 & & & & & & \\
\hline UMBELLIFERAE & Umbelliferae undiff. & & & 0.4 & & & & & \\
\hline$"$ & Daucus cf. D. carota L. & 0.7 & 0.5 & 0.4 & 0.4 & 0.2 & & & 0.3 \\
\hline$"$ & Orlaya grandiflora (L.)Hoffm. & 0.3 & & 0.2 & & & & & \\
\hline URTICACEAE & Parietaria & & & 0.2 & 0.9 & 0.4 & & & \\
\hline$"$ & Urtica dioica type & & & 0.4 & 0.5 & 0.4 & 0.9 & 1.0 & \\
\hline$"$ & Urtica pilulifera L. & & & 0.2 & 0.4 & & & & \\
\hline VALERIANACEAE & Valeriana & & 1.0 & & & 0.2 & & & \\
\hline VERBENACEAE & Verbena & & & & & & 0.2 & & \\
\hline
\end{tabular}

\begin{tabular}{c|c|c|c|c|c|c|c|c}
\hline HERB SUM & 86,8 & 64.3 & 61.8 & 30.1 & 31.9 & 21.1 & 15.3 & 12.1 \\
\hline CATEGORIES & & & & & & & & \\
\hline Trees & 7.1 & 27.1 & 17.6 & 64.1 & 64.3 & 70.5 & 73.7 & 59.2 \\
\hline Shrubs & 6.1 & 7.6 & 19.7 & 4.5 & 2.8 & 7.3 & 8.8 & 27.0 \\
\hline Lianes & & 0.5 & 0.4 & 1.3 & 1.0 & 1.8 & 1.9 & 0.7 \\
\hline Conifers & 10.8 & 26.7 & 1.3 & 2.2 & 2.8 & 5.5 & 5.2 & 19.7 \\
\hline Deciduos broadleaves & 2.4 & 8.1 & 14.6 & 58.6 & 58.4 & 70.1 & 77.3 & 67.3 \\
\hline Mediterranean sclerophylles & & 0.5 & 3.7 & 8.3 & 7.0 & 1.8 & 0.7 & 0.1 \\
\hline Total hygro-helo-hydrophytes & 1.4 & 5.7 & 3.9 & 4.0 & 4.8 & 2.2 & 5.0 & 2.8 \\
\hline Cereals & & & 1.3 & 1.3 & 0.8 & 0.7 & 0.5 & 0.5 \\
\hline Cultivated/cultivable herbs & & 1.7 & 1.5 & 0.8 & 0.7 & 0.5 & 0.5 \\
\hline
\end{tabular}




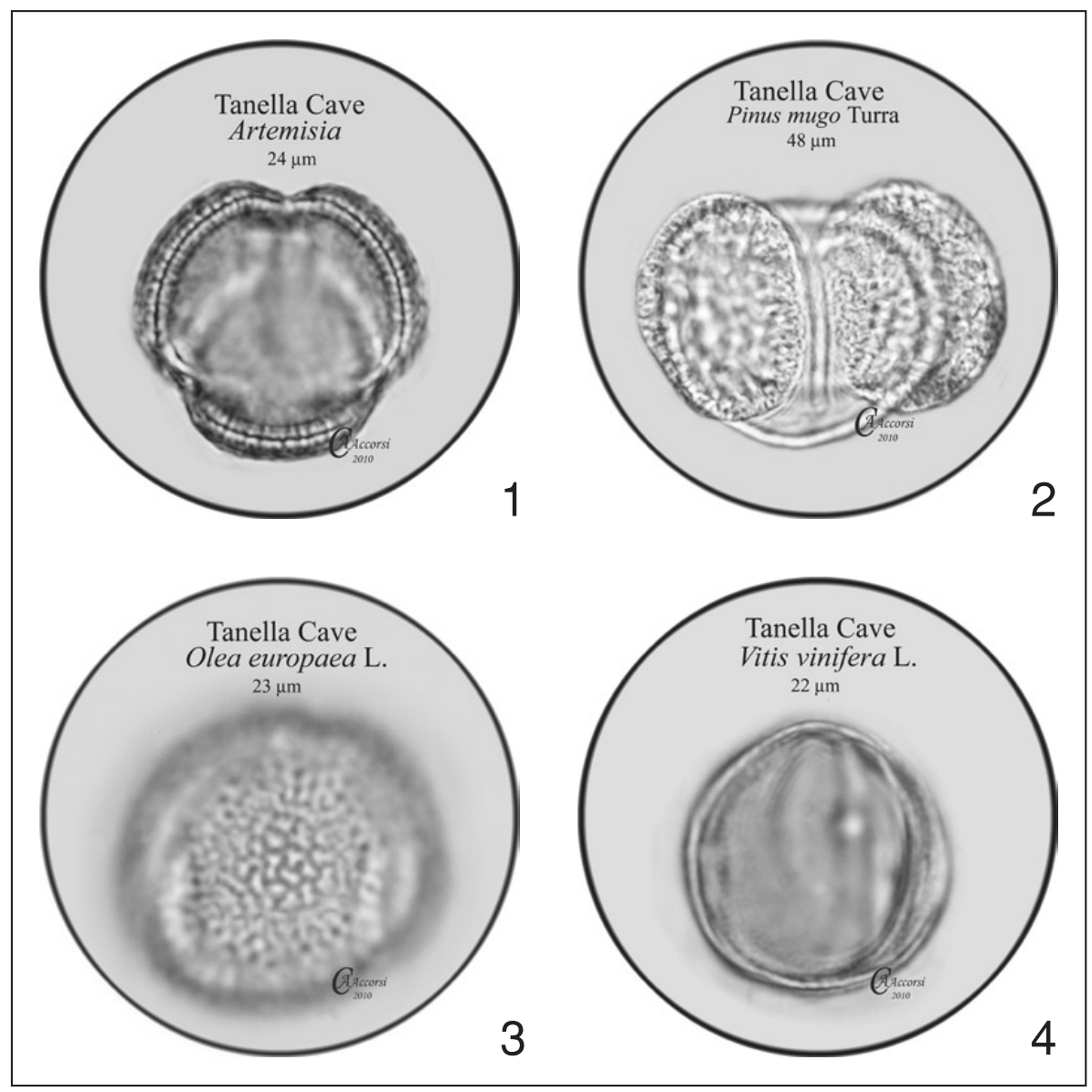

Fig. 8: 1 - 2 pollen grains recorded in samples 3; 3 - 4 pollen grains recorded in samples 1 (Photo: C. A. Accorsi).

present in all samples, whereas great-sized ones (class 1) were found only in the upper samples of the cave (samples $1,2,5)$.

Below is a description of the samples from the oldest to the recent.

Sample 4 - $120 \mathrm{~cm}$ depth; lithology of the level $(140-80 \mathrm{~cm})$ : gravel, sand and cobblestones; hypothesis of chronology: Last Glacial.

Pollen - Concentration is very low $\left(10^{1} \mathrm{p} / \mathrm{g}\right) ; 296$ pollen grains, plus 6 spores, were identified. Flora-Vegetation - Trees and shrubs are very low (13\%) and are mainly conifers. Several broadleaves were found in traces. Among herbs (87\%) Cichorioideae, largely dominant, are accompanied by Gramineae and a notable number of other taxa, including some hydro-hygrophytes and some pteridophytes. Micro-charcoals - The small-sized particles (classes $3,4,5)$ are very low $\left(10^{1} \mathrm{~m} / \mathrm{g}\right)$ and the greatsized ones are absent. Plant landscape - A landscape of alpine grassland, with traces of fresh water environments and small conifer stands is suggested by pollen. Climate appears to have been dry and probably cold. The presence of broadleaves may be interpreted in two different ways. Probably, these thermophilous trees indicate survival areas not far from the cave, but we can not esclude that their presence was due to the milder climate of an interstadial phase. The very homogeneous state of preservation of pollen grains allows to esclude the hypothesis of reworking of warm-temperate deposits. No fires, natural or anthropic, appear to have been lit in or near the cave.

Sample 3 - $65 \mathrm{~cm}$ depth; lithology of the level $(80-50 \mathrm{~cm})$ : silt with very thin layers of sand and gravel; hypothesis of chronology: Last Glacial.

Pollen - Concentration is a little higher $\left(10^{2} \mathrm{p} / \mathrm{g}\right)$ than in sample $4 ; 189$ pollen grains, plus 3 spores, were identified. Flora-Vegetation - Trees/shrubs increase (35\%). Conifers, namely pines, prevail (Pinus mugo, $P$. sylvestris, $P$. cembra together are $77 \%$ of woody pollen). Deciduous broadleaves are a little more abundant and more various. Quercus ilex was also recorded. Herbs are still dominant, but less abundant (65\%). Gramineae (dominant) are accompanied by several taxa, in part the same as previously, in part new entries. Hygro-helo-hydrophytes are more various and abundant. Micro-charcoals - The smallsized particles (classes $3,4,5$ ) are a little more abundant $\left(10^{2} \mathrm{~m} / \mathrm{g}\right)$ and traces of class 2 were found. Plant landscape - Trees, mainly pines, are spreading in the landscape and a riverside vegetation appears. Climate is a little warmer and wetter than before. Micro-charcoals increase, according to the increase of woody vegetation but, as in the previous sample, there is no evidence of fires lit in or near the cave.

Sample 2 - $25 \mathrm{~cm}$ depth; lithology of the level (50$20 \mathrm{~cm}$ ): nut-brown silt and reddish-brown clay; hypothesis of chronology: Roman period / Middle Age.

Pollen - Concentration is higher than before $\left(10^{3}\right.$ $\mathrm{p} / \mathrm{g}) ; 534$ pollen grains, plus 5 spores, were identified. Flora-Vegetation - Woody plants are similarly abundant as in sample 3 (38\%), but nearly half of them are shrubs, mainly Calluna with Erica and Genista. Among trees, 
Castanea largely prevails (it represents half of the trees), accompanied by Quercus and traces of several other taxa. Olea is quite well testified and so does Quercus ilex. Conifers are very scarce. Herbs are similar in abundance $(65 \%)$, but notably more various than in sample 3 , and include a number of anthropogenic records. Gramineae and Cichorioideae prevail (23\% and $22 \%$ respectively), followed by many other taxa. Hygro-helo-hydrophytes are quite well represented. In this sample, unambiguous evidence of human presence and activity appears, testified by a number of records: food and fodder plants (Castanea, Olea, Avena-Triticum group, Hordeum, Triticum, Leguminosae) and weeds (Centaurea nigra, Herniaria, Plantago lanceolata, Papaver rhoeas, Parietaria, Urtica dioica, Urtica pilulifera). Micro-charcoals - They have very high concentration, the highest recorded. The small-sized particles (classes 3,4,5) are $10^{5} \mathrm{~m} / \mathrm{g}$ and both the two classes of great-sized particles are present (classes 1 and $2=10^{1}-10^{2} / \mathrm{g}$ respectively). Plant landscape - A cultural landscape emerges from pollen: a secondary heath likely spread following forest clearance, pastures, large chestnut groves, olive groves, and cereal fields. Climate appears to have been warm with availability of water. Fires were lit in the area, near the cave too, most probably by humans. Concerning chronology, this sample could be assigned to the Roman period or the Middle age, based on the remarkable values of Castanea and Olea (Beghè 2008; Conedera et al. 2004).

Sample $1-10 \mathrm{~cm}$ depth; lithology of the level $(20-0 \mathrm{~cm})$ : slightly cemented gravel, cobblestones, sand, silt and reddish-brown clay; hypothesis of chronology: $19^{\text {th }}-20^{\text {th }}$ century.

Pollen - Concentration is similar to sample $2\left(10^{3} \mathrm{p} / \mathrm{g}\right)$; 551 pollen grains, plus 6 spores, were identified. Flora-Vegetation - The land picture changes. Forest cover is thick (trees and shrubs $=70 \%$ ). Conifers are just a little more abundant than before. Herbs are less abundant than before, but more diversified: Gramineae and Cichorioideae prevail, accompanied by a notable list of taxa among which cultivated plants and weeds. Hygrohelo-hydrophytes are well represented. Micro-charcoals - They continue to be high, with the same order of magnitude, but a little less abundant than in sample 2. Plant landscape - The landscape becomes similar to the current one. The large chestnut groves of sample 2 contracted and so did pastures and cereal fields, being replaced by natural bush/wood of Fraxinus ornus, Ostrya carpinifolia, Carpinus orientalis, deciduous Quercus, Q. ilex and by olive groves and vineyards. Weeds are more abundant than before. Pollen suggests a cultural, rural landscape. Climate appears to have been warm with availability of water. Fires were lit in the area, near the cave too, most probably by humans. Concernig chronology, the record of Ambrosia (also found in sample 5 and mosses) can help. Currently, some Ambrosia species grow in Veneto. One of them is autoctonous in Italy, but not in Veneto, and the others are American plants, which arrived in Europe in the $19^{\text {th }}$ century and are the most responsible of its spreading (Stepalska et al. 2002). Moreover, in this sample the ornamental alien trees testified in mosses were not recorded and micro-charcoals are more similar to sample 2 than to moss samples. Therefore sample 1 appears to be younger than sample 2 and older than moss samples, and its age can be tentatively considered $19^{\text {th }}-20^{\text {th }}$ century.

Sample 5 - $10 \mathrm{~cm}$ depth; lithology of the level $(20-0 \mathrm{~cm})$ : slightly cemented gravel, cobblestones, sand, silt and reddish-brown clay. Hypothesis of chronology: $19^{\text {th }}-20^{\text {th }}$ century.

Pollen and micro-charcoal content is very similar to the one of sample 1. Therefore the same discussion made for sample 1 can be valid for sample 5 .

Control samples 6 and 7 - moss samples near the cave, at the lower and higher entrance respectively. Age: recent (roughly the 2000s).

The two pollen spectra are very similar. In sample 6 there is an overrepresentation of Fraxinus ornus, due to local trees.

Pollen - Concentration is high - very high $\left(10^{5}-10^{6} \mathrm{p} / \mathrm{g}\right)$; 594 and 658 pollen grains, plus 3-6 spores, were identified respectively. Flora-Vegetation - Trees and shrubs are very abundant (80-85\%). Conifers are scarce. Deciduous broadleaves largely prevail. Olea is well represented, but less than in sampes 1 and 5 . Herbs are low (15-20\%) and not very diversified. They include both wild and cultivated plants. Freshwater plant communities are testified by Alnus glutinosa, Populus, Salix, Phragmites australis and Lemna. Marks of human activities in the landscape are fruit trees and cereals (Castanea sativa, Juglans regia, Olea, Prunus avium, Vitis, Hordeum, Avena-Triticum, Triticum) as well as antropogenic weeds (e.g., Plantago lanceolata, Rumex, Urtica dioica type), and some alien trees and shrubs, likely cultivated for decoration ( $\mathrm{Ce}$ drus, Platanus hybrida, alien Pinus, Thuja), which are also a marker of recent age. Pollen landscape matches the local bushy vegetation mainly shaped by Ostrya carpinifolia, Fraxinus ornus and Quercus, with Olea and Pistacia at lower altitude. Micro-charcoals - The small-sized particles (classes $3,4,5)$ are very high $\left(10^{6} \mathrm{~m} / \mathrm{g}\right)$, whereas the great-sized ones (class 1 and 2) are absent. No fires result to be lit near the cave currently.

Control sample 8 - moss sample, ca. $3 \mathrm{~km}$ far from the cave, at $937 \mathrm{~m}$ a.s.l. Age: recent (roughly the 2000s).

Pollen - Concentration is high $\left(10^{5} \mathrm{p} / \mathrm{g}\right) ; 612$ pollen grains, plus 3 spores, were identified. Flora-Vegetation - Trees and shrubs are very abundant (87\%). Conifers 
are notably more abundant than in mosses sampled near the cave (ca. 20\%). Deciduous broadleaves prevail. Olea is present in very low traces. The scarce herbs (13\%) include mainly Gramineae, accompanied by several taxa. The cultural character of the landscape is again given by trees and shrubs grown for decoration, fruit trees and cereals and weeds. Pollen landscape more or less matches the actual one. It is worthy to note the low values of Fagus and the high values of Ostrya compared with the actual diffusion of them in the area, due to the different plant production. Note also the high values of Picea, mainly cultivated. Microcharcoals - They are almost the same as in the moss samples near the cave (6 and 7).

\section{THE RECENT EVOLUTION OF THE CAVE AND CONCLUSIONS}

During the last glaciation, Monte Baldo was surrounded by the two large Lake Garda and Val d'Adige ice tongues, from which the highest ridge emerged. The Benàco ice tongue reached an altitude of about $1,100 \mathrm{~m}$ a.s.l. at Riva, $800 \mathrm{~m}$ at Malcesine and $500 \mathrm{~m}$ at San Vigilio (Venzo 1961). The withdrawal of the Lake Garda Würm glacier, which was completed some 12,000 years ago, gave origin to the large morainic amphitheater of Lake Garda and to considerable morainic deposits along the slopes of Monte Baldo, which have been preserved in several sites in the area of investigation, generally at altitudes of less than 600 m a.s.l. (Fuganti \& Panizza 1975).

During the Würm period, several small ice tongues were also active, which were fed by glacial cirques that can still be recognized quite easily and which came down from the peaks along the west site of Monte Baldo, towards the lake. These ice tongues eroded valleys in their descent, leaving various coarse deposits, which have been repeatedly reworked and eroded.

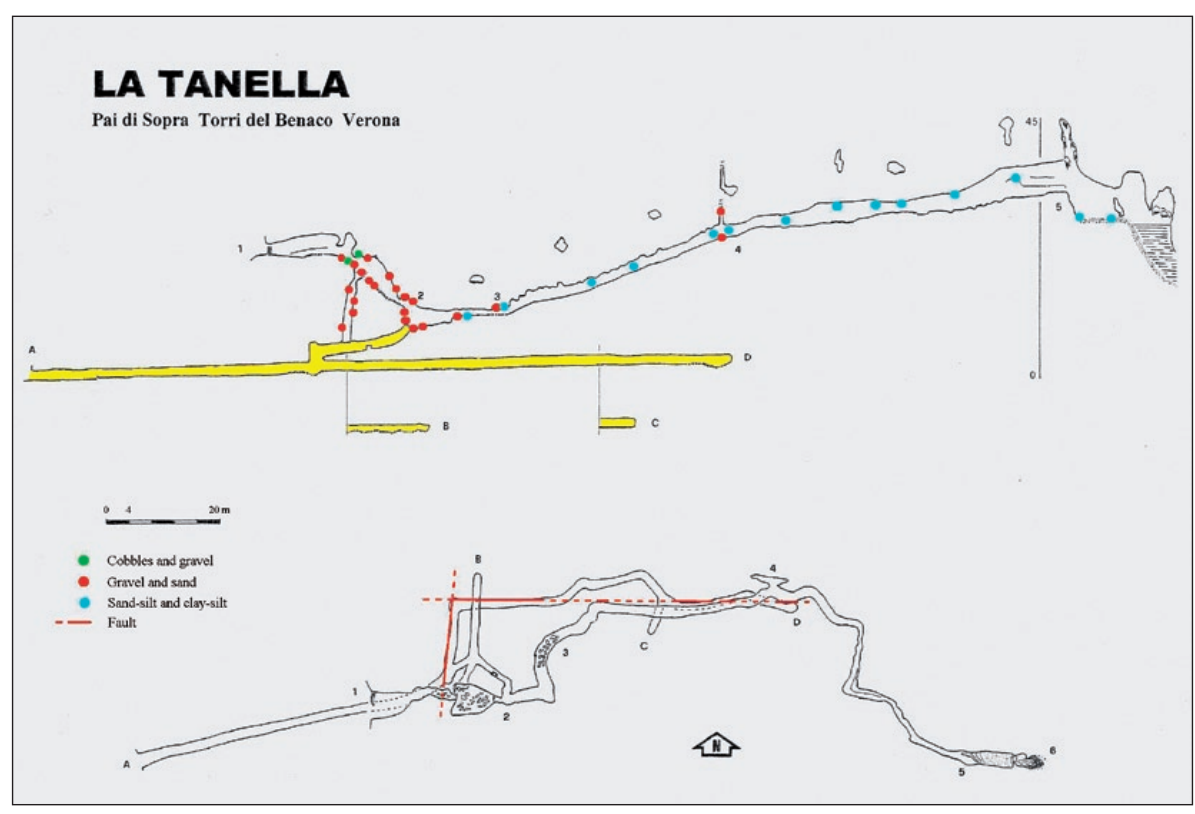

Fig. 9: Fluvioglacial deposits inside the cave. In yellow the excavated gallery.
At the end of the last glaciation, the water from the melting snow and glaciers contributed in a decisive manner to the rejuvenation of the local karst phenomena. The absorption of the carbonate mass must have been abundant in this period, and many streams flowed down the mountainsides, carrying enormous volumes of coarse and fine materials, facilitated by the steepness of the area. The Tanella cave functioned as an active spring, which drained a vast territory that must have gone up to altitudes of over 1,100-1,200 m, where many sinkholes were active. Part of the materials conveyed by the surface water courses was channelled inside these sinkholes, which were repeatedly blocked and emptied. The sediments that are now partially preserved in the Tanella cave were deposited in this situation. In particular, these deposits (rocks, pebbles, gravel, sand and clayey silt) were preserved more or less abundantly in various points of the cavity, often blocking fractures, scallops and cupola (Fig. 9). The observations made show that the largest sized materials were preserved near the natural entrance, while gravel and pebbles are located inside the shafts up to point 2. From this point up to point 4, there is gravel and sand alternated with sandy silt and clayey varved silt. These last sediments occupy various pockets, which are also situated near the vault of the keyhole passage, up to the terminal sump.

The study of these deposits enabled us to develop the following depositional sequence which is summarized in the following phases (Fig. 10):

1. The main water circulation takes place inside the phreatic gallery. Second- 
ary water arrivals are active in the chimney. The presence of large rounded rocks and pebbles near the natural entrance is ascribable to materials conveyed by the ice tongue (lateral moraine), while the coarse materials between points 2 and 4 come from the moraine and from chimney at point 4 . It would be difficult for them to derive from the terminal sump. Part of the natural entrance and all of the environments up to point 3 were completely blocked by coarse deposits. Under these conditions, the tract of the phreatic gallery located above became a lacustrine basin, where fine sediments with a varved texture were deposited. In the bottom of the cave, between points 1 and 3, there are natural losses of water in relation to small tectonic disturbances.

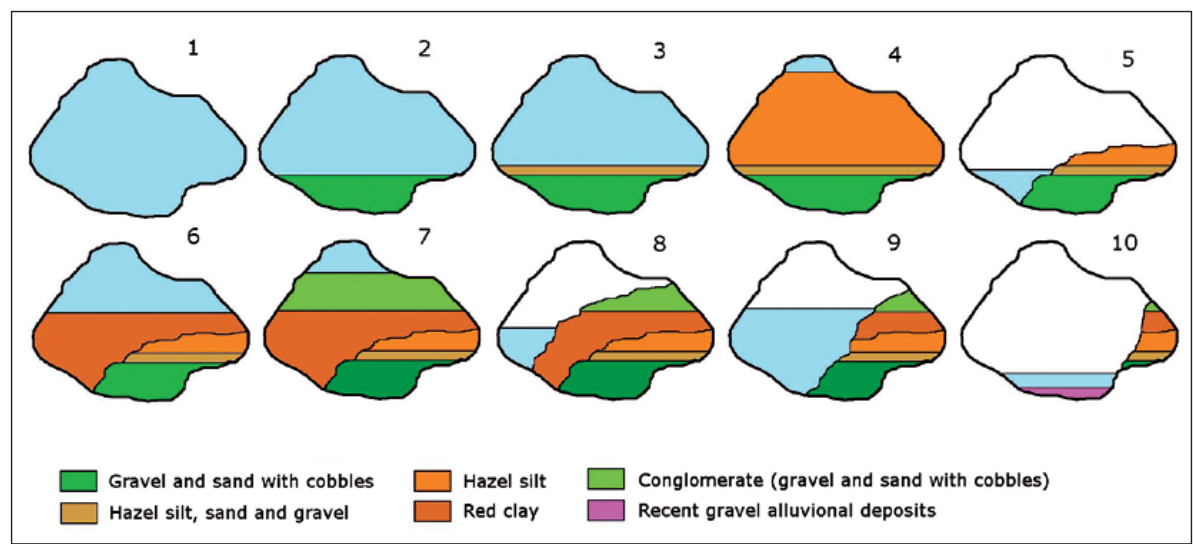

Fig. 10: Schematic sequences of the deposit and erosion phases and erosion inside the phreatic gallery (Drawing: R. Zorzin).

2. Minute gravel, sand, silt and clay continue to be conveyed and deposited in the phreatic passage above point 3 , which is completely sealed, up to the terminal sump. These sediments come primarily from the terminal sump (sand, silt and clay) and, secondarily, from the chimney at point 4 (gravel and sand).

3. Water circulation from the natural entrance and also from the underlying conduits, which produce only small losses, is deactivated.

4. The fluvioglacial deposits that blocked the phreatic passage are eroded, starting from the conduits present in the most depressed portions, consequently re-restoring water circulation. Deep circulation is reactivated towards areas of emergence at lower altitudes. The sublacustrine springs become very important.

5. Water circulation in the phreatic passage is deactivated, with a consequent vadose stage, which lasts for a short period of time. Residual red clay is deposited in the cavity, covering the residual fluvioglacial deposits in several points.

6. Successive blocking of the deep conduits takes place, consequently reactivating the phreatic conditions in the epigenetic gallery. The residual clay deposits with sedimentation of gravel and sand from the surface are partially eroded.

7. The artificial gallery is dug, intercepting the syngenetic gallery, which is emptied.

8. Pollen spectra from the cave show a vegetation history in which a largely open landscape of grassland above the timberline, probably of glacial age, moved towards a more and more forested landscape, progressively similar to the current one. In this time span, a few pollen flashes, possibly of late glacial, medieval and modern age, show the colonization of the land first by conifers, mainly pines, and then by deciduous broadleaves, mainly Quercus deciduous, Ostrya carpinifolia and Fraxinus ornus, with Quercus ilex as a last entry. In the Holocene pollen spectra, human contrasted the spreading of natural woody cover with cultivation of Juglans, Olea, Vitis, Cannabis and cereal field. Fires were lit near the cave. This action is less evident in recent moss samples, where only cultivation of Olea emerge, while Juglans, Vitis and cereals are in traces and Cannabis lacks. Also the management of fire is notably changed. Concerning the provenance of the plant particles, pollen grains suggest that they arrived into the cave mainly from its surroundings, rather than from higher altitude, because in Holocene samples (samples 2, $1,5)$ Olea is always present and conifers are scarce, as in the moss samples near the cave, while in the moss sample from higher altitude Olea is absent and conifers are abundant. Possibly some more conclusive evidence on this topic will be obtained from a surface sediment sample recently collected in the cave, very near to the examined sequence. Finally, it can be added that whatever has been the vehicle of pollen (water, air, animals), it appears to have been permanently submerged after its deposition due to its general good - very good state of preservation. Some exception for sample 2, where deteriorate pollen grains suggest episodes of oxidation and microbiological activity.

Currently, the cave functions as an "overflow" spring. The losses take place near and above the terminal sump. The terminal sump is hydrogeologically connected with the spring used by the "Camping ai salici" camping ground. 


\section{ACKNOWLEDEGMENTS}

Thanks to Prof. Fabio Tottola, project manager of "Water Project 2009”, Marina Feriotti and the lab. technicians, the students of IPSIA "E.Fermi” in Verona for the analyses.
A particular thank to Sergio Adami, Giuliano Acerbi, Andrea Ceradini and Alessandro Zorzin for the precious collaboration during the explorations and the tracing with fluorescein.

\section{REFERENCES}

Andersen, S.T., 1979: Identification of wild grasses and cereal pollen.- Årbog, 69-92.

Bartolomei, G., Broglio, A., Cattani, L., Cremaschi, M., Guerreschi, A., Mantovani, E., Peretto, C. \& B. Sala, 1982: I depositi würmiani del Riparo Tagliente.Annali Univ. Ferrara (Nuova Serie), 3, 4, 61-105.

Bartolomei, G., Broglio, A., Cattani, L., Cremaschi, M., Lanzinger, M. \& P. Leonardi, 1987-1988: Nuove ricerche nel deposito pleistocenico della Grotta di Paina sui Colli Berici (Vicenza).- Atti Istituto Veneto SS.LL.AA, 146, 11-160.

Beghè, D., 2008: Studio sulla variabilità genetica e sulla provenienza del germoplasma di Olea europaea $L$. in Emilia.- PhD thesis. Parma University, pp. 141.

Berglund, B.E. \& M. Ralska Jasiewiczowa, 1986: Pollen analysis and pollen diagrams.- In: Berglund, B.E. (ed.) Handbook of Holocene Palaeoecology and Palaeohydrology. John Wiley e Sons Ltd., pp. 455-484, Chichester.

Bertoldi, R., 1968: Ricerche pollinologiche sullo sviluppo della vegetazione tardi glaciale e postglaciale nella regione del lago di Garda.- Studi Trentini di Scienze naturali, Sez B, 45, 87-162.

Bertoldi, R. \& P.G. Andreolli, 1977: Analisi pollinologiche del deposito lacustre postglaciale di Santa Massenza.- Natura Alpina, 28, 75-82.

Beug, H.J., 1961: Leitfaden der Pollenbestimmung für Mitteleuropa und angrenzende Gebiete. Verlag Dr. Friedrich Pfeil, pp. 542, München.

Castellarin, A., Fesce, A.M., Picotti, V., Pini, G.A., Prosser, G., Sartori, R., Selli, L., Cantelli, L. \& R. Ricci, 1988: Structural and kinematic analysis of the Giudicarie deformation belt. Implications for compressional tectonics of Southern Alps.- Miner. Petrogr. Acta, 30, 287-310.

Cattani, L., 1976: Primi risultati delle analisi polliniche dei depositi tardi glaciali del Riparo Tagliente nei monti Lessini (Verona).- Annali Univ. Ferrara (Nuova Serie), 2, 10, 332-341.
Cattani, L., 1990: Steppe environments at the margin of the Venetian Pre-Alps during the Pleniglacial and Late - Glacial periods.- In: Cremaschi, M. (ed.) The loess in Northern Italy: a loess basin between the Alps and the Mediterranean region. Quad. Geogr. Fis. Dinam. Quat., 1, 133-137, Torino.

Ceradini, A., 2002: Grotte dei Lessini e del Baldo.- West Press Editrice, pp. 70, Verona.

Ceradini, A., 2004: La Tanella: una piacevole riscoperta.- Il Baldo - Quaderno Culturale, Grafiche P2, 15, 20-27.

Ceradini, A. \& A. De Angeli, 2007: La risorgenza di San Zeno.- Speleologia, 59, 24-27.

Conedera, M., Krebs, P., Tinner, W., Pradella, M. \& D. Torriani, 2004: The cultivation of Castanea sativa (Mill.) in Europe, from its origin to its diffusion on a continental scale.- Veget Hist Archaeobot., 13, $161-179$.

Faegri, K. \& J. Iversen,1989: Textbook of pollen analysis.John Wiley and Sons, pp. 328, Chichester.

Ferraro, F., 2009: Age, sedimentation, and soil formation in the Val Sorda loess sequence, Northern Italy.Quaternary International, 204, 54-64.

Fuganti, A. \& M. Panizza, 1975: La Geologia del territorio Gardesano.- Centro Studi e Ricerche Technital, pp. 296, Roma.

Mietto, P. \& U. Sauro, 1989: Grotte del Veneto. Paesaggi carsici e grotte del Veneto.- Tipolitografia "La Grafica”, pp. 413, Vago di Lavagno.

Monegato, G., Ravazzi, C., Donegana, M., Pini, R., Calderoni, G. \& L. Wick, 2007: Evidence of a two-fold glacial advance during the last glacial maximum in the Tagliamento end moraine system (eastern Alps).- Quaternary Research, 68, 284-302.

Moore, P.D., Webb, J.A. \& M.E. Collins, 1991: Pollen analysis. - II ${ }^{\circ}$ ediz., Blackwell Sc. Publ., pp. 216, Oxford.

Paganelli, A., 1984: Storia climatico-forestale del Pliocene e del Quaternario.- In: Aspes A. (ed.) Il Veneto nell' antichità preistoria e protostoria, Vol. I. Banca Popolare di Verona, pp. 69-141, Verona. 
Pasa, A., 1954: Carsismo e idrografia carsica nel group del M. Baldo e nei Lessini veronesi.- C.N.R., Centro Studi Geografia Fisica, Ricerche sulla morfologia e idrografia carsica, 5, Tipografia Mareggiani, pp. 150, Bologna.

Pignatti, S., 1982: Flora d'Italia. I $^{\circ}-\mathrm{II}^{\circ}-\mathrm{III}^{\circ}$ vol. - Edagricole, pp. 790, pp. 732, pp. 780, Bologna.

Punt, W. (ed.), 1976 : The Northwest European Pollen Flora, I.- Elsevier, pp. 145, Amsterdam.

Punt, W. \& G.C.S. Clarke (eds.), 1980 - 1991: The Northwest European Pollen Flora, II,III,IV,V.- Elsevier, pp. 265 , pp. 138 , pp. 369 , pp. 154 , pp. 275 , Amsterdam.

Punt, W., Blackmore, S. \& P.P. Hoen, (eds.), 1995: The Northwest European Pollen Flora, VII.- Elsevier, pp. 275, Amsterdam.

Punt, W., Blackmore, S., Hoen, P.P. \& P.J. Stafford (eds.), 2003, 2009: The Northwest European Pollen Flora, VIII, IX.- Elsevier, pp. 183, pp. 187, Amsterdam.

Ravazzi, M., 2005: Il Tardoglaciale: suddivisione stratigrafica, evoluzione sedimentaria e vegetazionale nelle Alpi e in Pianura Padana.- Studi Trent. Sci. Nat., Acta Geol., 82, 17-29.

Reille, M., 1992-1998: Pollen et spores d'Europe et D'Afrique du Nord; Supplement I ; Supplement II.- Laboratoire de botanique historique et palinologie, URA CNRS 1152, pp. 521, pp. 327, pp. 520, Marseille.

Roghi, G. \& R. Romano, 2008: Le formazioni geologiche del Veronese nella nuova Cartografia Geologica Nazionale.- La Lessinia Ieri Oggi Domani - Quaderno Culturale, Tipolitografia "La Grafica", 79-88, Vago di Lavagno.
Sauro, U. \& M. Meneghel, 1980: Dati preliminari sulla neotettonica del Foglio 21 (Trento) p.p., 35 (Riva) p.p., 26 (Schio) p.p., 49 (Verona).- C.N.R., Prog. Fin. Geod. Pubbl., Officine Grafiche Napoletane, 331-357.

Sauro, U. \& D. Zampieri, 1999: Una montagna in evoluzione.- Il Monte Baldo, Cierre Edizioni, 53-88.

Sorbini, L., Accorsi, C.A., Bandini Mazzanti, M., Forlani, L., Gandddini, F., Meneghel, M., Rigoni A. \& M. Sommaruga, 1984: Geologia e geomorfologia di una porzione della pianura a sud-est di Verona."Mem. Mus. Civ. Sto Nat. Verona", II serie, sez. Scienze della Terra, 2, pp. 91, Verona.

Stępalska, D., Szczepanek, K. \& D. Myszkowska, 2002: Variation in Ambrosia pollen concentration in Southern and Central Poland in 1982-1999.- Aerobiologia, 18, 13-22.

Torri, P., Accorsi, C.A., Bosi, G., Forlani, L. \& M.C. Montecchi 2009: Un metodo per contare i microcarboni nei preparati pollinici.- In: Di Marzio, P., Fortini P. \& G.S. Scippa (eds.) Le scienze botaniche nela cultura e sviluppo economico del territorio, Riass. $104^{\circ}$. Congr. Naz. Soc. Bot. It., $16^{\text {th }}-19^{\text {th }}$ September 2009, Campobasso. Università degli studi del Molise, 278, Campobasso.

Venzo, S., 1961: Rilevamento geologico dell'anfiteatro morenico del Garda. Parte II ${ }^{\circ}$ : tratto orientale GardaAdige e anfiteatro atesino di Rivoli Veronese.- Mem. Soc. It. Sc. Nat., XIII (11), pp. 64, Milano. 